By what path does it arrive? How long does it stay? How does the distribution of phosphorus depend on abnormal conditions of diet or disease ?

Investigations such as these are now beginning in various laboratories. They will not be restricted to the study of phosphorus, for other elements of interest in bodily metabolism such as calcium, potassium, iron, etc., are available in active modifications. I think it is clear that this method of radioactive indicators has many interesting possibilities, for its power and delicacy make it possible to attack problems which have so far been inaccessible to experiment.
There are also other applications of the radioactive modifications of suitable elements. If an element is concentrated in certain organs, then these organs can be subjected to selective irradiation by using an active isotope of the element. For example, radio-phosphorus can be used to irradiate bone and bone marrow, or spleen; radioiodine for thyroid, etc. So little work has been done on these lines that it would be premature to discuss these therapeutic applications further. They may, however, prove to be important and among the most spectacular results of experiments on artificial transmutation.

\title{
History of the Fenland*
}

$\mathrm{W}$ ITHIN historic times, the English fenland stretched over the greater part of the area to the west and south of the Wash, extending as far north as Lincoln and as far south as Huntingdon and Cambridge. On the seaward side, the surface deposits are semi-marine silts, laid down, and afterwards occupied, during the RomanoBritish period. On the landward side, the upper layers are peat produced by discharge of the flood waters of the Rivers Witham, Welland, Nene and Ouse into the extensive shallow basin of the fens. The fen peats are alkaline and therefore support a vegetation of the true 'fen' type. Very little of the original vegetation of the peat fen remains, however, since the whole area has been drained and brought under extensive cultivation. Its present characteristics are the black peaty soil, uniform flatness and deep ditches full of reeds (Phragmites communis) which separate fields of cereals, potatoes and sugar beet.

Cambridge is at the head of the fens, and the town and University have become the centre of the activities of the Fenland Research Committee, formed in 1932 under the presidency of Sir Albert Seward, and aided by grants from - the British Association, the Percy Sladen Trust and the Department of Scientific and Industrial Research. Thus have the geology, botany, archæology, stratigraphy and climate of the fenland area been closely investigated. One fen area which has yielded exceptionally valuable results is Wicken Fen, the largest area still uncultivated, covering about one square mile, now in the hands of the National Trust, and lying about ten miles to the north-east of Cambridge on the margin of the fenland itself.

\footnotetext{
* Based on the evening discourse by Dr. H. Godwin to the British
} Association at Cambridge on August 19.
Very little is known of the fenland in glacial times; for most of our knowledge of the area we must turn to the post-glacial period, during which the most important single key to its history lies in the recognition of the land- and sea-level movements which have left their record in the deposits of the basin.

The upper layers are very similar to those of the German coastal marshes. Although the peat is continuous at the margin, it is soon separated into an upper and lower layer by wedging out of soft grey clay. The lower layer contains brush. wood of oak, pine and alder; the upper layer contains some tree remains and above this a layer of Sphagnum peat of a type similar to that of the large red bogs of the central Irish plain. In certain parts there is a layer of calcareous shell-marl overlying the Sphagnum peat. This reflects very changed conditions, since Sphagnum could not have grown in water so deep or so calcareous. From investigations of the diatoms and foraminifera of the fen clay, it is concluded that it was deposited in brackish water and that there was also considerable marine influence. This shows that a phase of freshwater peat formation with fen woods was interrupted by a marine transgression, and that, after the upper peat had formed, a phase of increased wetness produced shallow lakes.

In places nearer the sea, there is upper silt several feet thick and several feet above sea-level. Its foraminifera content shows it to represent another marine phase. The upper peat extends below it at about ordnance datum for many miles seawards. The surface of this silt shows abundant traces of Romano-British occupation. In parts, the upper peat has been worn away by drainage and cultivation, exposing the surface of the fen clay at ordnance datum. Thus evidence is found 
of two periods of freshwater conditions and two periods of marine transgression as major phases in fenland history.

The lowest and oldest deposits of fenland, however, are out in the North Sea, where big deposits of moorlog have been discovered. These deposits have been found in water as much as $200 \mathrm{ft}$. deep, and have been shown to contain many species characteristic of the present-day fens or Norfolk Broads. That these deposits may be looked upon as the earliest phase of fenland history has recently been established by the technique of pollen analysis. By identification and statistical analysis of pollen in the deposits, not only can the species of plants be identified but also their periods of dominance. For example, in south Germany there was an early phase of birch-pine dominance, then a phase of hazel, then a replacement of conifers by mixed

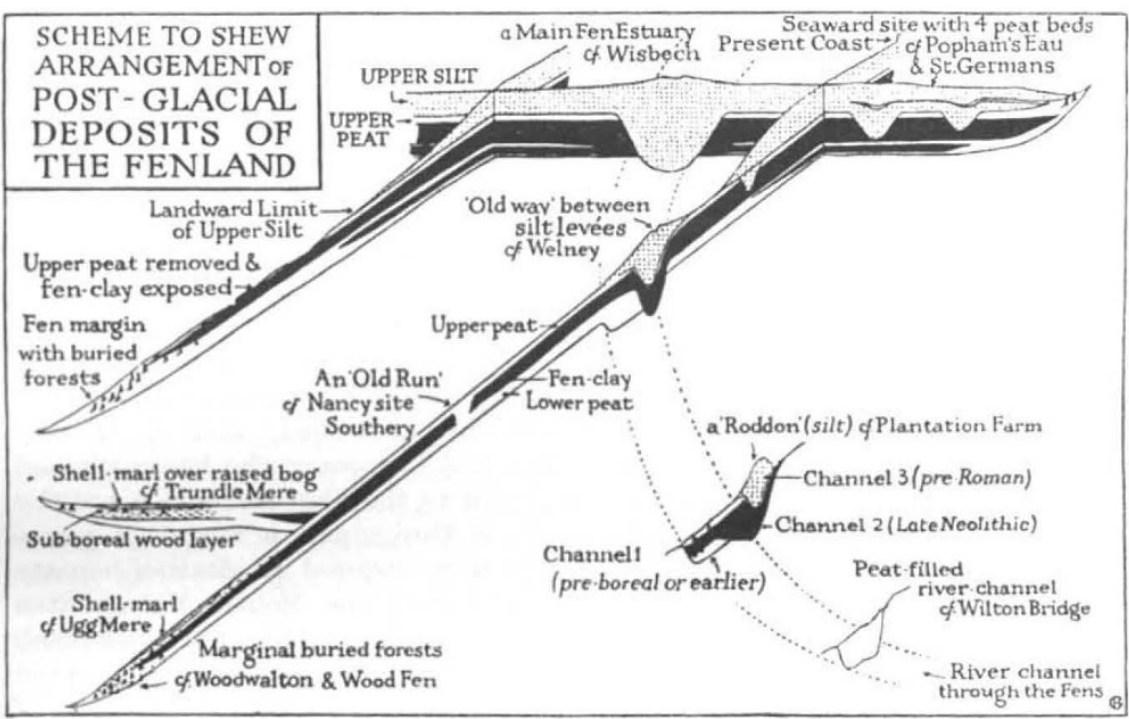

From "A Scientific Survey of the Cambridge District", PREPared for the

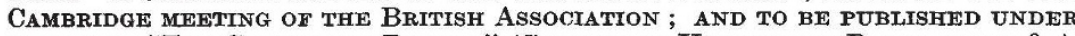
the tirle "The Cambridge Region" (Cambridge Untversity Press, price 68.).

oak woods followed by beech dominance, culminating in an increase in spruce and fir possibly to be attributed to the felling of beech in historic times.

These phases of forest history have been correlated with archæological remains. For example, the Bronze Age was contemporary with the greatest expansion of beech, and the hazel maximum corresponded with the Tardenoisian. Forest history has been correlated not only with archæological horizons but also with climatic and geological events ; thus is forest history dateable in years and may be utilized as an index to all kinds of events of the past. For example, the analysis of a peat bed now buried under salt marsh on the Norfolk coast revealed a marked sequence of phases. To begin with, pine and birch dominated, then hazel, then pine which was later displaced by oak and elm and more especially alder. The last transition was at the Boreal-Atlantic level. Since this pre-Boreal peat is now $10 \mathrm{ft}$. below ordnance datum, the sea must have been $20 \mathrm{ft}$. lower in relation to land than it is now; but pollen analysis of the peat from the floor of the North Sea shows that it was in fact much lower than this. The analyses made show only pinebirch with negligible amounts of other trees or hazel, and they almost certainly relate to the preBoreal. They are from depths so great as 30 fathoms, so that it is very probable that at this time (about 8000 years B.c.) the North Sea was at least $200 \mathrm{ft}$. lower in relation to the land than now, and the fens extended right over most of the present floor of the North Sea. As the sea formed during the following centuries, more recent peats were restricted to the shallower coastal areas. The considerable age of the deeper peats has been confirmed by the discovery of a bone fish spear of Mesolithic type in a lump of peat dredged by fishing boats from the Leman and Ower banks off the Norfolk coast.

The excavations and inquiries of the Fenland Research Committee have been limited to the more landward sites. Of particular interest was the excavation of an ancient river channel at Shippea Hill, between Ely and Mildenhall. Here, no fewer than three archæological horizons were discovered stratified into

the fen deposits.

Broadly speaking, the fenland history has shown alternating phases of marine invasion and of freshwater conditions. The first freshwater phase in the present fens extended through the Mesolithic and Neolithic periods, and for much of the time the fens were covered with alder-birch fen woods. It was probably about the end of the Neolithic period that marine invasion caused formation of the fen clay. In the Bronze Age which followed, fen woods grew extensively, but these must have been dry enough for prehistoric man, since Bronze Age remains are found abundantly in the fen peats. It is probable that the fens became too wet for occupation in the Iron Age.

In the Roman period, marine invasion once 
again dominated fenland history. All the silt of the Wisbech-Spalding area was laid down and its surface intensively cultivated. Along the tidal rivers, silt banks were built up and stood above the surrounding peat land as habitable areas.

After the Romans left Britain, the fens were not exploited until the drainage which began seriously in the seventeenth century. As it became effective, the shallower lakes, such as Whittlesea Mere, Soham Mere and Benwick Mere disappeared. The ground-level sank by shrinkage and wastage of the peat, often as much as one inch a year, and the silt banks of the Romano-British water courses began to appear as raised banks, or 'roddons', crossing the peatland.

There is no reason for supposing that the land and sea movement, which has played such a large part in former fenland history, has now ceased entirely. There is some evidence that recent drainage troubles in the fens are due in part to sinking of the coast. It seems possible that the subsidization of work like that of the Fenland Research Committee would be of value not only to science in general, but also to such scientific applications as the drainage of the fenlands.

\section{Obituary Notices}

\section{Dr. Charles Carpenter}

$\mathrm{B}$ Y the death of Dr. Charles Carpenter on September 7 at the age of eighty years, industry loses one of its greatest administrators and applied science one of its staunchest advocates. Trained from his youth as a gas engineer and with an intimate knowledge of gas engineering practice, his delight in precision caused him to realize the value of allying the scientific mode of thought to engineering practice. It was this combination of science and practice which gave the keynote to his technical work. The development of the Metropolitan Argand No. 2 burner was an example of his personal interest in accuracy of detail and the desire to express a quantity so difficult of measurement as illuminating power with the greatest precision possible. It was recognition of the need for closer co-operation between the scientific and the practical man that led him to take so keen an interest in the work of the Society of Chemical Industry, of which he was president in 1915-17, and the dominating theme of both his presidential addresses was the necessity for bringing the often impractical chemist into closer touch with the engineer, whose work was incomplete without the co-operation of a man viewing things from a more academic viewpoint.

Dr. Carpenter's belief that a vigorous chemical industry was necessary to the welfare of Great Britain was behind the strong support he gave to the formation of the Association of British Chemical Manufacturers. During the Great War, his work as adviser to the Ministry of Munitions was made possible by the deep interest he had taken in the practical application of science, and when in 1917 the Advisory Council for Scientific and Industrial Research decided to establish a Fuel Research Board, Dr. Carpenter was able to give material assistance in arranging for a site and facilities to be placed at the Board's disposal. As a member of the Coal Conservation Committee appointed by the Ministry of Reconstruction in 1918, he showed his belief in the importance of applying scientific methods to the problems of fuel treatment and utilization. The value of his work in designing and putting into production gas burners of standardized characteristics and of ensuring a gas supply unchanging in chemical composition and properties has, in later years, received the recognition that it deserves; but the introduction of what seemed to many unnecessary refinements in the control of gas quality and in the removal of naphthalene and sulphur made him appear often to occupy a position of isolation among his contemporaries.

As a pupil and the successor of Sir George Livesey, it was to be expected that the ideals of co-partnership should form the keynote of his relationship with the employees whom he controlled, and if Livesey planted a sapling, it is Carpenter who has cultivated it until it has grown to the dimensions of a healthy tree. His career is throughout a record of painstaking devotion to duty inspired by ideals of honesty and fairness. Entering the South Metropolitan Gas Co. as an engineering pupil at its Vauxhall works, his unusual ability caused him to be appointed to the position of works engineer at the age of twenty-six years, and on the death of Sir Frank Livesey in 1899 he was appointed chief engineer of the Company. When in $1908 \mathrm{Sir}$ George Livesey died, he was chosen by the Board of Directors to succeed him as their chairman, a position which he held, with the altered title of president, until illhealth compelled his retirement in 1937.

E. V. E.

WE regret to announce the following deaths :

Cavaliere Filippo de Filippi, Hon. K.C.I.E., a wellknown Italian explorer, who led the Italian expedition of 1913-14 to the Himalaya, Karakoram and Eastern Turkestan, on September 23, aged sixty-nine years.

Prof. Derrick Norman Lehmer, emeritus professor of mathematics in the University of California, on September 8, aged seventy-one years.

Dr. A. S. Mackenzie, president of Dalhousie University, Halifax, Nova Scotia, during 1911-31, formerly professor of physics in Bryn Mawr College, Dalhousie University and the Stevens Institute of Technology, aged seventy-three years. 